\title{
Radyo, Televizyon ve Sinema Anabilim Dalındaki Doktora Tezleri Üzerine bir İçerik Analizi
}

\author{
DOI: 10.26466/opus.832924
}

*

\author{
Çilem Tuğba Koç* \\ * Dr. Öğr. Üyesi, Erciyes Üniversitesi İletişim Fakültesi Kayseri/Türkiye \\ E-Posta: takdag@erciyes.edu.tr \\ ORCID: $\underline{0000-0002-3479-4035}$
}

\section{Öz}

Lisansüstü üretilen tezler üzerine incelemeler, bilimsel çalışmaların gidişatın ve durumunu ortaya koymaları açısından son derece önemlidir. İlgili çalışmalara bakıldığında, iletişim alanında üretilen lisansüstü çalışmaların niteliğiyle ilgili araştırmalara rastlanmış, ancak Radyo Televizyon ve Sinema Anabilim dalında üretilen doktora tezleriyle ilgili herhangi bir çalışmaya rastlanılmamıştır. Çalışmada, Radyo Televizyon ve Sinema Anabilim dalında üretilen 260 doktora tezi içerik analizi yöntemiyle incelenmiştir. Son on yılllk süreci izlemek için, 2010-2020 tarihleri arasında üretilen tezlere Yök'ün Ulusal Tez Arama sayfasından ulaşılarak, yılları, üniversiteleri, konuları, alanları, kullandıkları yöntem ve teknikler bakımından değerlendirilmeye tabi tutulmuştur. Araştırma sonucunda, Radyo Televizyon ve Sinema Anabilim dalında üretilen tezlerin yöntemleri incelendiğinde, çalışmaların, $\% 36,9^{\prime} l ı k$ bir oranla en fazla nitel yöntemle gerçekleştirildiği görülmüştür. Sinema üzerine olan tezlerin ise, \%19,2'sinin teorik bilgi birimine katkı sunan çalışmalar olduğu diğer önemli bir kısmının $(\% 80,8)$ ise veri incelemelerinden (film çözümlemesi, görüşme sonuçlarl, anket değerlendirmesi gibi) oluştuğu görülmüş̧ür. Inceleme sonucunda ortaya çıkan başka bir çarpıcı sonuç ise, film çözümlemeleri üzerine olan tezlerin \%40,6'sinda ( $n=26)$ filmlerin belli bir yöntem ve tekniğe göre incelenmesi, \%59,3'ünde $(n=38)$ herhangi bir yöntem ve tekniğe göre incelenmemiş olduğunun ortaya konulmasıdır.

Anahtar Kelimeler: ̇letişim Eğitimi, Radyo, Televizyon ve Sinema, Doktora Tezleri, İçerik Analizi, İletişim Araştırmaları. 


\title{
A Content Analysis on Phd Theses in the Department of Radio, Television and Cinema
}

\begin{abstract}
Researches on doctoral dissertations are extremely important in the sense that they reveal the direction and status of scientific studies. Reviewing the literature, it is seen that there are researches on the quality of postgraduate studies produced in the field of communication, but no studies on doctoral theses produced in the field of Radio, Television and Cinema. With this respect, 260 doctoral dissertations conducted in the department of Radio, Television and Cinema have been analyzed by content analysis method. In order to have a retrospective outlook on the last ten years, the theses published between the years of 2010 and 2020, have been accessed from YOK's National Thesis Searching Page and evaluated in terms of publishing year, name of the university; subject, field, methods and techniques were used. According to the study results, qualitative researches are the most applied study design with $36.9 \%$. Another striking result of the analysis is that in $40.6 \%(n=26)$ of the studies in the field of cinema, the films have been analyzed based on a certain method and technique, whereas in $59.3 \%(n=38)$ there were no specific methods nor techniques have been found.
\end{abstract}

Keywords: Education of Communication, Radio, Television and Cinema, Doctoral Dissertations, Content Analysis, Communication Research 


\section{Giriş}

İletişim eğitimine tarihsel süreç içerisinde bakıldığında, basının ilk olarak ortaya çıkının ardından, 1908 yılında ABD'de Missouri Üniversitesinde kurulan gazetecilik okuluyla başladığı söylenmektedir (Uzun, 2006, s. 120). Amerika'da gazetecilik eğitimi iletişimin bir disiplin olarak gelişmesinden çok önce kurulmuş ve yaygınlaşmıştır. İletişim bilimlerinin bir alan olmasında Kurt Lewin ve Carl Hovland gibi psikologların yanında Harold Lasswell ve Paul Lazarsfeld gibi siyaset bilimcilerin katkısı sayılmaktadır (Pooley ve Park, 2012, s.76). İletişim bilimleri eğitimi ise, Wilbur Schramm'ın IOWA Üniversitesi Gazetecilik Bölüm Başkanıyken, 1943 yılında iletişim bilimleri alanında doktora programını açmasıyla başlayacaktır. 1960'lı yıllarda, W. Schramm ve arkadaşları iletişim çalışmalarının kurumsallaşarak bir alan haline gelmesini sağlamıştır (Rogers 2004, s. 8).

ABD'deki iletişim mezunlarının sayısı 1970 ile 1990 yılları arasında, \%35 oranında artış göstermiştir (Uzun, 2006, s. 120). Kitle iletişimi ile ilgili araştırmalar, bu araçların tarihsel gelişimi içerisinde önce gazetelerin, sonraları ise sinema ve radyonun yaygın olarak kullanılmaya başlanılması ile bu araçlarla ilgili olarak yapılmaya başlanmıştır (Aziz, 2006, s. 4). Türkiye'de iletişim eğitimi veren ilk kurum, 1949 yılında, İstanbul Üniversitesi İktisat Fakültesi bünyesinde kurulan Gazetecilik Enstitüsü olmuştur. Ancak, Türkiye' de de gazetecilik eğitiminin mesleğin özelliklerine uygun bir müfredatla verilmesi, 1965 yılında Ankara Üniversitesi Siyasal Bilgiler Fakültesi'ne bağlı Basın-Yayın yüksekokulunun kurulmasıyla başlamıştır (Avcı, 1998, s. 14). 1990'lı yıllara kadar, Türkiye'de lisans düzeyinde iletişim eğitimi sadece İstanbul, Ankara, Marmara, Hacı Bayram Veli (Gazi), Ege ve Eskişehir Anadolu üniversitelerinde verilirken; bu tarihten sonra Akdeniz, Atatürk, Bahçeşehir, Başkent, Bilgi, Galatasaray, Kocaeli, Maltepe, Selçuk ve Yeditepe üniversitelerinde de iletişim eğitimi verilmeye başlanmıştır (Ünlü, N, ve D, 1999, s. 92). 2000'li yıllara gelindiğinde ise, bu üniversitelere ilave olarak Türkiye'nin dört bir yanında açılan iletişim fakültelerinin sayısında önemli bir artış kaydedilmiştir.

Yök' ün sayfasında yer alan 2019-2020 verilerinden elde edilen bilgiye göre 34'si devlet üniversiteleri, 6'sı özel ve vakıf üniversiteleri olmak üzere, 40 farklı üniversitede aktif olarak iletişim eğitimi verilmektedir. Bölüm bazında bakıldığında ise, İletişim Bilimleri alanında 5, Radyo, Televizyon ve Sinema alanında 48, sadece Sinema başlığında ise hepsi vakıf üniversiteleri olmak 
üzere 5 üniversitenin aktif olduğu görülmüştür. Bahsi geçen bölümlerle birlikte, 2 vakıf üniversitesinde ise Televizyon Haberciği ve Programcllı̆g bölümlerine rastlanılmıştır. Ayrıca, İletişim Bilimleriyle birlikte, 7 vakıf üniversitesinde Medya ve İletişim Bölümü, yine 7'sinde Yeni Medya bölümlerine de rastlanmıştır. 1990'lı yıllarda İletişim Bilimleri Müfredatı temel alınarak kurulan İletişim Fakülteleri'ndeki ana bölümlerden biri olan Radyo, Televizyon ve Sinema bölümünün, son yıllarda vakıf üniversitelerinin sayısındaki artışa paralel olarak Sinema, Yeni Medya, Medya Araştırmaları gibi ayrıştırılmış başlıklar altında da verildiği görülmektedir. İletişim alanındaki bu parçalı yapı, lisansüstü eğitimin durumuyla ilgili soruları da beraberinde getirmektedir.

Açılan iletişim fakültelerinin sayısındaki artışla birlikte, yeni medya bölümlerinin açılması, sinema ve fotoğraf gibi alanların, iletişim fakültelerinin dışında da güzel sanatlar altında eğitim vermeye başlaması gibi birçok faktör bir araya gelince, verilen eğitimin de niteliği daha çok konuşulmaya başlanmıştır. İletişim eğitimiyle ilgili kısa bir araştırmada bile, en çok araştırma yapan kişinin iletişim alanının duayenlerinden biri olan Oya Tokgöz olduğu görülecektir. Tokgöz'ün 2006 yılında Kültür ve İletişim Dergisi'nde yayınlanan "Türkiye'de Illetişim Fakültelerindeki Eğitim Kadrosunun Durumu: Eleştirel bir Değerlendirme" başlıklı makalesi, iletişim eğitimi veren kadroların kurumsallaşmış bir lisansüstü eğitimden geçmeleri gerektiğine işaret etmektedir. Tokgöz YÖK doktora programlarından geçerek halen devlet ve vakıf üniversitelerinin iletişim eğitimi kadrosunu oluşturan öğretim üyelerinin İstanbul, Marmara, Ege, Anadolu, İstanbul, Ankara, Gazi, Selçuk, Kocaeli, Galatasaray Üniversiteleri'nde dağılmış olarak yer aldıklarına dikkat çekmiştir. Bununla birlikte, ikinci olarak da YÖK'le birlikte iletişim alanında yetiştirilen eğitim kadrosu yanında, farklı disiplinlerde yetiştirilmiş bulunan eğitim kadrosunun doktora eğitim programlarında ders verdiğini vurgulamıştı (Tokgöz, 2006, s. 66)

Benzer bir çalışma, Akgül ve Akdağ (2018) tarafından da yapılmıştır. Araştırmada, kamu üniversiteleri bünyesinde bulunan, 38 iletişim fakültesindeki 678 öğretim üyesinin hangi alanlardan geldiklerini araştırmıştır. Araştırma sonucuna göre, 187 akademisyen dilbilim, işletme, siyaset bilimi, sosyoloji, felsefe, psikoloji, antropoloji, tarih gibi iletişim alanı dışından toplum- 
bilimlerin farklı alanlarından geldikleri tespit edilmiştir. Buna karşın, doktorasını iletişim alanında tamamlamış öğretim sayısının nispeten daha fazla olduğu bulgusuna ulaşılmıştır (Akgül ve Akdağ, 2018, s.17).

İletişim Bilimleri, her ne kadar farklı isimler altında alt dallara ayrılarak, giderek daha parçalı bir hale gelse de iletişim fakültelerindeki lisansüstü ders müfredatlarına bakıldığında birçok dersin her üç program için, özel alana yönelik dersler haricinde, iletişim bilimlerine yönelik oldukları dikkat çekmektedir. İletişim alanı dışındaki disiplinlerden eğitimcilerin varlığı, bir taraftan iletişimin alanının diğer alanlarla olan ilişkisi bağlamında zenginleştireceği gibi araştırmaların yöntem ya da nitelik yönünden tartışılması sorununu da beraberinde getirmektedir. Farklı disiplinlerden gelen yöntem ve tekniklerin iletişim alanına uygulandığı pek çok çalışma iletişim alınan katkı sunmakla birlikte, sosyal bilimlerin bazı alanlarında görülen yöntem ve tekniğin olmaması sorununun iletişim çalışmalarına da sirayet etmesi, iletişim alanındaki çalışmaların herhangi bir disipline sahip olmadığı yönündeki tartısmalara zemin hazırlamaktadır. Değirmenci'ye göre (2011, s. 78), disiplinler arasılığa temel eleştirilerden birisi, yöntemin belirsizliği ya da sinırsızlığı olsa da disiplinler arası bütünleştirici yaklaşımların neticesinde, disipline olmamış bir disiplin ortaya koymasıdır. Bu duruma örnek olarak ise, kültürel çalışmalar ve iletişim alanı gösterilmiştir (Değirmenci, 2011, s.78). Verilen örnekten anlaşıldığı üzere, yöntemin belirsizliği alanın bir disiplin olarak görülüp görülmeyeceğine belirleyecektir. Söz konusu durum ise, iletişim alanındaki lisansüstü tezlerin bilimsel olarak niteliğini, sistematik karakterini tutulan metodolojiyi gündeme getirmektedir.

Tokgöz'ün çalışmasına dönecek olursak, çalışmada 1988 ile 2003 yılları arasında en çok doktora tezi üreten üniversitelerin İstanbul, Ankara, Ege, Marmara, Anadolu, Selçuk ve Gazi (Hacı Bayram Veli) olduğu tespit edilmiştir. Dikkat edilirse, en çok tez üretilen üniversitelerin aynı zamanda devlet ve vakıf üniversitelere giden kadroların da sahibi olduğu görülecektir. Diğer bir ifadeyle doktora tezleri, iletişim fakültelerinin ana kadrolarında yer alan öğretim üyelerinin bağlı bulunduğu üniversitelerde fazla sayıda çıkmıştır. İletişim alanındaki 260 doktora tezine inceleyen Tokgöz İstanbul Üniversitesi'nden 86, Marmara'dan 64, Ankara'dan 36, Ege'den 31, Anadolu'dan 30, Selçuk'tan 12, Gazi'den ise 7 doktora tezine ulaşmıştır (Tokgöz, 2006, s. 55). Araştırma sonucuna göre, en çok doktora tezi Halkla İlişkiler alanında olduğunu 
onu Televizyon alanının izlediğini, üçüncü sırayı ise Gazetecilik alanının aldığını ifade etmiştir. Alanlar içinde Sinema alanına değinilmemiş olması dikkat çekicidir. Çalışmada ikinci olarak doktora tezlerinin konularına değinilmiştir. İletişim alanındaki doktora tezlerinde en çok kitle iletişim araçları/sistemleri, popüler kültür, basın tarihi, reklam ve pazarlama, yeni iletişim teknolojileri, iletişim hukuku ve radyo yayınları konusunun öne çıttğı tespit edilmiştir. Tokgöz ayrıca YÖK kategorisine giren tezlerin ne şekilde ve nasıl hazırlandığı konusunun yani yöntem ve tekniklerin önemle üzerinde durulması gerektiğini ifade etmiştir (Tokgöz, 2006, s. 56). Araştırmaya göre, YÖK kategorisinde yer alan doktora tezleri kullanılan yöntem ve teknikler, üniversitelere göre farklılık göstermiştir. Doktora tezlerinde en çok tercih edilen veri analiz tekniği ise, içerik analizi çıkmıştır (Tokgöz, 2006, s. 55). Çalışmada dikkat çeken bir diğer tespit ise, Tokgöz'ün Radyo, televizyon ve gazetecilik eğitimi konusunda yapılmış bulunan çalışmaların sayısı ise yok denecek kadar az bulmuş olmasıdır (Tokgöz, 2006, s. 56)

Gerçekten de bu iddiayı destekler nitelikte, ilgili literatür incelendiğinde, Radyo Televizyon ve Sinema alanında yayınlanmış olan lisansüstü tezleri inceleyen iki çalışmaya rastlanmıştır. Bu çalışmalardan ilki, Çağrı İnceoğlu'nun “Türkiye'de Sinemayı Konu Alan Doktora Tezleri Üzerine Bibliyometrik Bir Çözümleme" (2014) isimli çalışmasıdır. Çalışmada, 1985-2013 yılları arasında Yök'ün tez arama sayfasında yayınlanmış olan sinema üzerine yapılmış 199 doktora tezinin incelenmesiyle gerçekleştirilmiştir. Sinema alanındaki doktora tezlerinin \%78,89'u bu tarihten sonra üretilmiştir (İnceoğlu, 2014, s. 38). İnceoğlu (2014) 2000'li yıllardan itibaren yerli sinema üzerine olan tezlerin sayısındaki artışın olduğunu ifade ederek,bu durumun arkasında yatan sebebin son yıllardaki yerli film izleyicisinin sayısının yaklaşık yedi katına çıkmış olmasını göstermiştir. Sinema alanında üretilmiş doktora tezleri, biçem incelemeleri, auteur, göstergebilimsel, psikanalitik, feminist, ideolojik, tarihsel, toplum bilimsel, felsefi, bilişsel yaklaşımlar, yıldız ve izleyici, postmodernizm, tür eleştirisi ve ulusal sinema olmak üzere sinema araştırmalarında dünden bugüne rol oynamış olduğu bilinen belli eleştirel yaklaşım, yöntem ve kuramlar çerçevesinde sınıflandırılmıştır. Araştırma sonucuna göre en fazla yararlanılan yöntemin \%19,82'lik bir oranla toplum bilimsel yaklaşım olduğu bulunmuştur (İnceoğlu, 2014, s. 44). Bununla birlikte, sinema alanında edebiyat, grafik, hukuk, işletme, ilahiyat gibi farklı disiplinlerin iletişim alanıyla uzlaştırılması sonucu ortaya çıkan çalışmaların arttığına dikkat çekilmiştir (İnceoğlu, 2014, 
s. 97). İnceoğlu'na göre (2014, s. 32), Radyo Televizyon ve Sinema alanındaki disiplinler arası çalışmalardaki artış, toplum bilimsel bakış açısının güçlendiğini göstermektedir.

İkinci çalışma ise, Fırat Tufan tarafından, 2019 yılında, 2010-2017 yılları arasında hem Yök'ün veri tabanından yurt içinde üretilmiş hem de Proquest veri tabanı üzerinden yurtdışındaki lisansüstü tezlere ulaşılması yoluyla gerçekleştirilmiştir. Radyo alanıyla ilgili 105 teze ulaşılan çalışmada, radyo alanındaki çalışmalarda 2016 yılından sonra bir artış gözlendiği sonucuna varılmıştır (Tufan, 2019, s. 120). Radyo alanında yazılan tezlerin çoğunluğunun İstanbul, Marmara ve Anadolu Üniversiteleri'nden çıtıkları, toplamda 7 olan doktora tezinin 4'ünün ise Marmara Üniversitesi'ne ait olduğu ortaya çıkarılmıştır (Tufan, 2019, s.121). Çalışmada, Radyo alanında yazılmış olan tezlerin büyük çoğunluğunda, alan araştırmasına dayalı anket ve görüşme gibi araştırma teknikleri kullanıldığı bulunmuştur (Tufan, 2019, s.122) Çalışma bulguları arasında belki de dikkat çekici başlık araştırmaların konuları ile ilgili olduğu görülmüştür. Gerek yurtiçinde gerekse yurtdışındaki tez çalışmalarının konu olarak en çok Radyo ve siyaset ilişkisiyle birlikte, radyo ve müzik çerçevesindeki konularda yazıldığı tespit edilmiştir. Topluluk radyoları, radyonun toplumsal etkisi ve radyo-reklam ilişkisi diğer sık çalışılan konular olmuştur. Özellikle topluluk radyoları ve radyo-demokrasi ilişkisi Türkiye'de olduğu gibi Amerika ve Kanada'da da çokça önemsenen konulardır. Buna karşın dünyada sıklıkla çalışlan öğrenci radyoları ve eğitsel radyolar Türkiye'de yeterince ilgi görmeyen konular olmuştur (Tufan, 2019, s. 126).

Radyo Televizyon ve Sinema alanıla ilgili doğrudan olmamakla beraber iletişim alanı içinde inceleyen son dönemde yayınlanmış bir başka değerli çalışma ise Davulcu ve Mazıcı (2018) tarafından, 2006-2016 yılları arasında, 895 doktora tezi üzerine gerçekleştirilmiş olan araştırmadır. Davulcu ve Mazıcı'ya göre (2018, s. 72) bilimin ilerlemesi ve katma değer yaratması açısından doktora tezlerindeki durumun tespit edilmesinin önemi, sonraki yapılacak olan çalışmalara yol göstermesi ve iletişim çalışmalarının niteliğini artırabilecek olmasıdır (Davulcu \& Tanyeri Mazıcı, 2018, s. 72). Doktora tezlerinin daha çok medya çalışmaları, yeni iletişim teknolojileri, kurumsal iletişim ve halkla ilişkiler uygulamaları, sinema çalışmaları, pazarlama iletişimi ve reklamcılık konularında yoğunlaştığı ortaya çıkarılmıştır. 2008 yılından sonra doktora tezlerinde sosyal medya (yeni medya) konusunun ön plana çıktığ1 tespit edilmiştir (Davulcu ve Tanyeri Mazıcı, 2018, s. 61). Çalışmada sinema 
alanıyla ilgili olarak, veri analiz teknikleri altında \%4,7'lik bir oranla film çözümlemesi yapıldığı tablolaştırılmıştır (Davulcu ve Tanyeri Mazıcı, 2018, s. 61). Yine aynı çalışmada, Türk ve Dünya Sineması'ndan örnek film incelemelerinin daha çok tercih edildiği sonucuna ulaşılmıştır. Politik ve kültürel eleştiri, temsil, darbe, gerçeküstücülük, modernizm ve postmodernizm, gözetim, tüketim kültürü, sömürgecilik, toplumsal muhalefet, estetik, etik, suç, şiddet, yabancılaşma, milliyetçilik, kentleşme, nostalji, korku, melankoli, kahramanlık, güldürü ve sinema; edebi uyarlamaların sinemadaki yeri, sinemada mekân ve oyunculuk, sinema filmlerin denetlenmesi, senaryo eleştirisi gibi konuların sinema alanında öne çıkan konular olduğu bulgusuna ulaşılmıştır. (Davulcu ve Tanyeri Mazıcı, 2018, s. 62)

Buraya kadar bahsedilen çalışmaların haricinde, Radyo Televizyon ve Sinema alanlarındaki tez çalışmalarını değerlendiren bir çalışma olmadığı gibi doğrudan Radyo Televizyon ve Sinema Anabilim dalında üretilen doktora tezlerini değerlendiren bir çalışmaya da rastlanılmamıştır. İnceoğlu'nun 2014 yılında yaptığı çalışma sadece sinema konusu üzerinden araştırılmıştır. Bu çalışmada, İnceoğlu' nun çalışmasından farklı olarak, Radyo Televizyon ve Sinema Anabilim dalı altında yer alan bütün konulara bakılmak istenmiştir. Son on yılda, Radyo Televizyon ve Sinema Anabilim dalında üretilen doktora tezleri incelenmek istendiği için 2010-2020 yılları arasında, YÖK'ün Ulusal Tez Merkezi'nden ulaşılan 260 tez üzerinden nicel içerik analizi yapılmıştır. Radyo Televizyon ve Sinema Anabilim dalında, doktora alanındaki tezlerin durumunu ortaya koyma amacında olan bu araştırmada, amaca bağlı olarak aşağıdaki araştırma sorularına cevap aranmıştır:

- Tezlerinin yıllara göre dağılımı nedir?

- Yayınlanan tez miktarı yıllara göre bir artış ya da azalma göstermiş midir?

- Tezlerin yayınlandıkları üniversiteler ile tezlerinin sayısı arasında anlamlı bir farklılık var mıdır? Eğer anlamlı bir farklılık bulunmaktaysa, üniversitelere göre toplam tez sayısının yıl bazındaki dağılımı nedir?

- Tezler hangi alanlarda ve konularda yapılmıştır?

- Tezlerin konuları ile alanları arasında anlamlı bir farklılık var mıdır?

- Eğer anlamlı bir ilişki bulunmaktaysa, tezlerin alanlara göre konu dağılımı nasıldır?

- Tezlerde kullanılan yöntem ve teknikler nelerdir? 
- Tezlerin yayınlandıkları üniversiteler ile kullanılan yöntemler arasında anlamlı bir farklılık var mıdır? Eğer anlamlı bir farklılık bulunmaktaysa, kullanılan yöntemlerin üniversitelere göre dağılımı nedir?

- Tezlerin alanları ile kullanılan yöntem ve teknikler arasında anlamlı bir farklılık var mıdır? Eğer anlamlı bir fark var ise dağılımı nasıldır?

- Tezlerin konuları, kullanılan yöntem ve tekniklere göre nasıl dağılmıştır?

\section{Araştırmanın Yöntemi}

Radyo Televizyon ve Sinema Bilim Anabilim Dalı'nda 2010-2020 arasındaki son 10 yıllık dönemde yayınlanmış olan doktora tezleri incelenmesinde objektif, sistematik bir veri analiz tekniği olan nicel içerik analizi kullanılmıştır. Önceleri medya analizlerinde kullanılan içerik analizi, sosyal bilimlerin diğer alanlarında da sıklıkla uygulanan bir teknik olmuştur. Son yıllarda, iletişim alanındaki çalışmaların durumunu ya da iletişim eğitimiyle ilgili sorunları ve genel eğilimi ortaya koymaya yönelik çalışmalara bakıldığında da içerik analizinin sıklıkla kullanıldığı görülmüştür. Nicel içerik analizi araştırma probleminin belirlenmesinden başlayarak, varsayımların ortaya atılmasına; varsayımlar doğrultusunda değişkenlerin belirlenmesine; nitel değişkenlere nicel değerler atanmasına; değişkenler arasındaki ilişkinin istatistiksel olarak ölçülmesine ve bulguların tablolar ya da grafikler yardımıyla açıklanmasına kadar belli aşamaları olan bir analiz tekniği olarak tanımlanmaktadır (Riffe, Lacy, ve Fico, 2014, s. 19). İçerik analizinin nesnel olması, araştırma bulgularına araştırmacının kendi yorumunu ya da beklentisini katmadan araştırma sonuçlarını olduğu gibi açık ve objektif bir dille ifade etmesidir. Çalışmada, araştırma sonuçlarıyla ilgili değerlendirmeler araştırma bulguları yerine sonuç kısmında dile getirilmiştir.

İncelenen dönemde, Radyo Televizyon ve Sinema Bilim Anabilim Dalı'nda ulusal çapta üretilen doktora tezlerine, Ulusal Tez Merkezi'nin web sayfası olan www.yok.gov.tr adresinden ulaşılmıştır. Tezlere ulaşıldığında, çoğunlukla tezlerin özet kısımlarında tezin amacı, yaklaşımları, kullanılan yöntem ve tekniklere ilişkin bilgilerin eksik olduğu tespit edilmiştir. Bu nedenle, tezin tamamını görmek için, incelenen zaman aralığında, Radyo Televizyon ve Sinema Anabilim dalında üretilmiş olan 265 tez içinden, izinsiz olan 5 tez inceleme dışı tutularak, 260 tez incelemeye dahil edilmiştir. İncelemeye alınan tezlerin tamamına bakıldığ için ayrıca örnekleme alınmamıştır, 
incelemeye alınan 260 tez örnekleme çerçevesini oluşturmaktadır. Tezlere ulaşmak için, tez arama sayfasındaki detaylı arama sekmesi kullanılarak, Radyo Televizyon ve Sinema Anabilim Dall, doktora tezleri, tümü, dili Türkçe ve durumu izinli ve incelenen tarih aralığı bazında bir seçim yapılarak filtrelenmiştir. Ulaşılan doktora tezlerinin İstanbul, Marmara, Ege, Galatasaray, Hacı Bayram Veli (Gazi), Ankara ve Selçuk üniversitelerinde olduğu görülmüştür. Tezlerin her biri inceleme birimi olarak seçilmiştir. Araştırma soruları doğrultusunda, tezin yılı, tezin yayınlandığı üniversitenin adı, tezin alanı, tezin konusu, tezde yer alan konu başlıkları, tezde yer alan diğer konu başlıkları, tezin yöntemi, tezde kullanılan diğer yöntem ve teknikleri, tezde kullanılan veri analiz teknikleri şeklinde kategoriler belirlenmiştir. Belirlenen kategoriler, istatistiksel olarak değerlendirmek üzere SPSS 22.0 programına kategorik değişken olarak kodlanmıştır. Kategorik değişkenlerin karşılaştırılmasında ve ölçülmesinde içerik analizi içinde değerlendirilen frekans ve ilişki analizleri yapılmıştır. Tezlerin tümü değelendirilmeye alınmış olup, her değişken için eksiksiz kodlama yapıldığı için herhangi bir kayıp değer tanımlanmamıştır. Nitel değişkenlerin karşılaştırılmasında çapraz tablolar kullanılmıştır. Bulgu sunumunda sadeliği ve anlaşılırlığı sağlamak amacıyla, yapılan her çapraz tabloya bulgu sunumunda yer verilmemiştir. Örneğin, tezlerin konuları çok değiştiği ve tabloya sığmadığı için alanlara göre konuları ya da yöntemleri karşılaştırma yaparken, tablo yerine yazı ile ifade edilmesi tercih edilmiştir. Yine de alandaki araştırmacılara fikir verebilmesi için tez başlıkları önce SPSS 22.0'a tek tek işlenmiş, daha sonra konularına göre kategorilendirilerek diğer konular şeklinde tabloda sunulmuştur.Bununla birlikte, çapraz tablolar, gerekli olduğu durumlarda sunumda görsel olarak yer almıştır. Nitel değişkenlere göre gerçekleştirilen betimsel analizlerin açılanmasında ve gösteriminde frekans $\chi 2$ analizi kullanılmıştır. İki değişken arasındaki anlamlılık düzeylerinin ölçülmesinde $\mathrm{p}<0,05$ olarak kabul edilmiştir.

\section{Bulgular}

Yökün tez arama sayfasında, Radyo Televizyon ve Sinema alanındaki tezlerin yayınlandığ1 yıllar incelendiğinde, en fazla tezin, 2016 ( $n=41 ; \% 15,5)$ ve 2019 (n=36; \%13,8) yıllarında yayınlamış oldukları görülmüştür. Buna karşın, en az tezin $2020(n=8 ; \% 3,1)$ yılında yayınlanmış olduğu görülmüştür. Tez yıl- 
larına göre, tezlerin dağılımına bakıldığında, 2011, 2014 yıllarında az tez sayıda bir düşüş gözlenmiştir. Bununla birlikte, tez sayılarında 2017 yılında dramatik bir düşüş yaşandığı gözlemlenmiştir. 2010 yılından, 2016 yılına kadar ise, tez sayısının kademeli bir biçimde arttı̆̆ tespit edilmiştir. Tezler yıl bazında değerlendirildiğinde, 2010 yılında 10; 2011 yılında 9; 2012 yılında 28; 2013 yılında 29; 2014 yılında 24; 2015 yılında 31, 2017 yılında 16; 2018 yılında toplam 28 tezin Radyo, Televizyon ve Sinema Anabilim dalında yayınlamış oldukları görülmüştür. Tezlerin yıllara göre değişimi şekil.1'de gösterilmektedir.

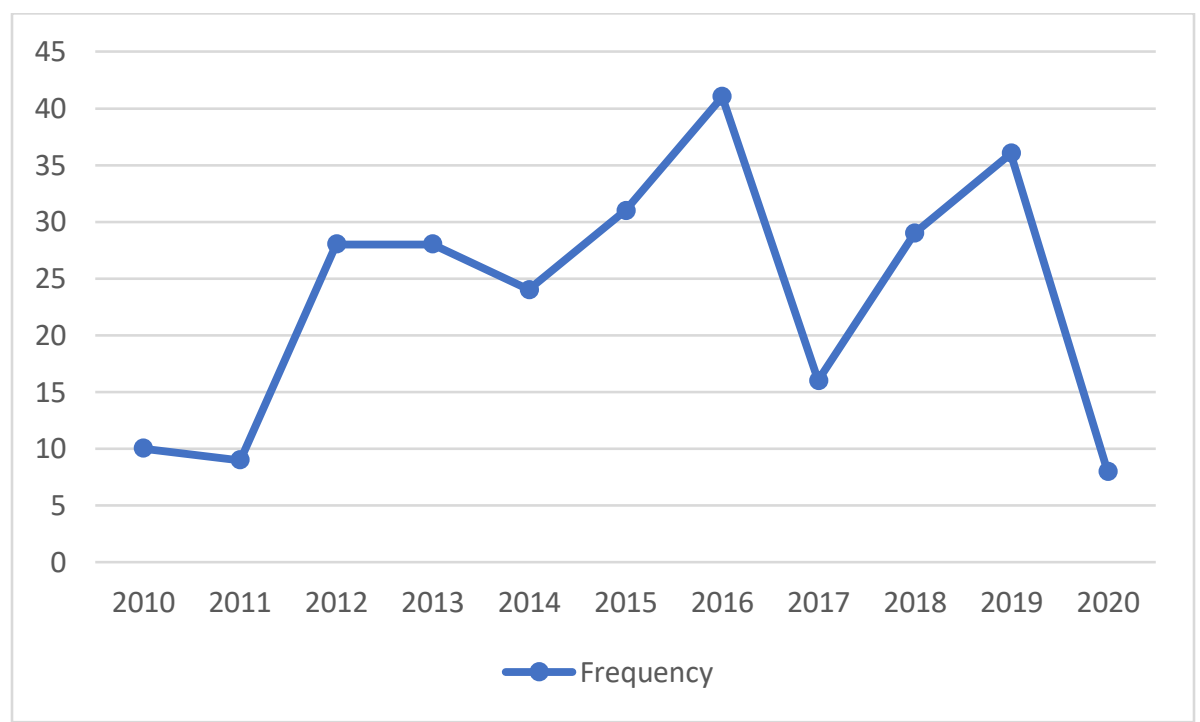

Şekil 1. Tezlerin Yıl Bazında Dağılımı

Radyo Televizyon ve Sinema Anabilim Dalı'na göre, 2010-2020 yılları arasında yayınlanmış doktora tezleri araştırıldığında, bu tezlerin, tamamının kuruluş tarihi bakımından diğer iletişim fakültelerine göre daha eski ve devlet üniversitelerine bağlı iletişim fakülteleri olduğu saptanmıştır. Araştırma sonucuna göre tezlerin yayınlandığı üniversitelerin, İstanbul, Marmara, Ege, Galatasaray, Hacı Bayram Veli (Gazi Üniversitesi), Ankara ve Selçuk Üniversitesi'ne ait oldukları belirlenmiştir. 


\section{A.S. Tezlerin Yayınlandıkları Üniversiteler İle Tezlerinin Sayısı Arasında Anlamlı Bir Farklılık Var Midır?}

İncelenen tarih aralığında, üniversitelerde yayınlanan doktora tezleri ile say1ları arasında anlamlı bir farklılık bulunup bulunmadığına bakılmıştır. Ki Kare testin sonucuna göre, $x 2(n=260) ; p=0,001<0,05$. Ho hipotezi red, H1 hipotezi kabul edilmiştir. İncelenen zaman aralığında, yayınlanmış tezlerin oranlarının üniversitelere göre farklılık gösterdiği tespit edilmiştir. Buna göre, en fazla tezin \% 33,8'lik bir oranla İstanbul Üniversitesi İletişim Fakültesi tarafından üretildiği söylenebilir. İstanbul Üniversitesi İletişim Fakültesi'ni surasıyla; \%22,4 ile Marmara Üniversitesi; \%16,9 ile Ege Üniversitesi, $\% 13,1$ Ankara Üniversitesi; aynı oranla $(\% 4,6)$ Galatasaray ve Hacı Bayram Veli (Gazi) Üniversitesi; \% 4,2 ile Selçuk Üniversitesi izlemiştir. Üniversitelerin yıl bazındaki doktora sayıları karşılaştırıldığında, Selçuk Üniversitesinde 2015 yılına kadar hiç doktora tezi görülmezken, en çok doktora tezinin 2019 yılında üretildiği belirlenmiştir. Hacı Bayram Veli (Gazi) Üniversitesinde 2015; Ege Üniversitesi'nde 2019, Ankara Üniversitesi'nde 2014, İstanbul Üniversitesi'nde 2018, Marmara Üniversitesi'nde 2016, Galatasaray Üniversitesi'nde ise 2017 yıllarında en fazla tezin üretildiği görülmüştür. 2010 ile 2013 yılları arasında diğer üniversitelerde tezlerin üretilmesine karşın, Selçuk, Hacı Bayram Veli ve Galatasaray Üniversitesi'nde Radyo Televizyon ve Sinema Anabilim dalında doktora tezinin üretilmemiş olduğu bulgusuna ulaşılmıştır.

\section{A.S. Tezler Hangi Alanlarda Ve Konularda Yapılmıştır?}

Yayınlamış olan tezler incelendiğinde, en fazla tez sayısının sinema alanında ( $\mathrm{n}=119$; \%45,8) olduğu görülmüştür. İkinci olarak, en fazla tez sayısı televizyon alanında $(n=57 ; \% 21,9)$ olduğu tespit edilirken; üçüncü sıranın yeni medya alanına ( $\mathrm{n}=41 ; \% 15,8)$ ait olduğu belirlenmiştir. Son on yılda, özellikle sosyal medyanın popüler olarak kullanılması, yeni medya alanına olan ilgiyi arttırmış, bu durum ise doktora tezlerinin yeni medya alanına kaymasına neden olmuştur. Araştırmada dikkat çeken en önemli bulgulardan biri ise, Radyo Televizyon ve Sinema Anabilim dalını oluşturan üç alan içinde, radyo alanına ilişkin tez sayısının azlığıdır. Radyo alanına ilişkin radyo, radyo ve televizyon konu başlı̆̆ında tezlere rastlanmıştır. Her iki konu başlığında da 2 'şer tez olmak üzere 4 adet radyo alanıyla ilgili doktora tezi olduğu tespit 
edilmiştir. Ana alanların dışında ancak iletişim eğitimi içinde olan gazetecilik alanıyla ilgili 8; siyasal iletişimle ilgili 7; iletişim bilimleriyle ilgili 6 adet, fotoğrafçılık alanıyla ilgili 4 , reklamcılık alanıyla ilgili 2 adet doktora tezi yayınlanmıştır. İletişim alanının diğer alanlarla konu bakımından kesişimi sebebiyle, tarih, sanat, felsefe, eğitim, pazarlama gibi alanlarda da tezlere rastlanmıştır. Bu alanların dışında, iletişim alanıyla doğrudan hiçbir ilişkisi olmayan müzik terapisi, müzecilik gibi alanlarda az da olsa (\%0,8'lik bir oranla) teze rastlanmıştır.

\section{A.S. Tezlerin Konuları İle Alanları Arasında Anlamlı Bir Farklılık Var Midir?}

Analiz sonucunda, x2 ( $n=260$ ); p=0,007<0,05. Ho hipotezi red, H1 hipotezi kabul edilmiştir. Yani, tezler alanlarına göre farklılık göstermektedir. Radyo ve Televizyon alanında üretilen tezlerin \%5,3'ünün radyo televizyon yayıncillğıyla ilgili olduğu saptanmıştır. Televizyon alanında ise \%2,3'nün medyanın ekonomi politiği ile; \%1,5'inin çocuk; diğer bir \%1,5'inin modernleşme ve \%1,4'ünün tüketim kültürü, \%1,1'inin haber ile ilgili olduğu tespit edilmiştir. Sinema alanında tez sayısının fazla olması, tez konuların oranlarının diğer üç alana göre daha fazla çıkmasına neden olmuştur. Sinema alanında en çok öne çıkan konular ise; \%14,6'sının Türk Sineması, \%4,3'ünün toplumsal cinsiyet; \%3,4'ünün dijitalleşme; \%3,07'sinin Dünya Sinemas1; \%3,8'inin uluslaşma ve modernleşme; \%1, $9^{\prime}$ unun belgesel; $\% 1,5^{\prime}$ inin toplumsal bellek konularının oluşturduğu görülmüştür. Bunlarla birlikte, çocuk, ayrımcllık, tüketim kültürü, haber, animasyon, İslamafobya, kimlik ve temsil, film estetiği, sinema seyircisi, film estetiği gibi konulara da rastlanmıştır. Son olarak en fazla tez üretilen alan olması sebebiyle yeni medya alanındaki konulara bakılmıştır. Yeni medya alanında, en çok \%6, $5^{\prime}$ lik bir oranla yeni iletişim teknolojilerine yönelik çalışmaların ağırlık kazandığı görülmüsstür. Bu bağlamda, "ağ toplumu" kavramını ele alan çalışmalar ile internet teknolojisinin televizyon yayıncılığı üzerindeki etkileri ve dijitalleşme konularını inceleyen araştırmaların yeni medya alanında ağırlık kazandığı görülmüştür. Sanıldığının aksine, sosyal medya konusu daha az yeni medya çalışmaları içinde yer almıştır.

Çalışmalar incelendiğinde, sosyal medyanın toplumsal hareketlere etkisi ve kamuoyu oluşturma gücü gibi siyasal iletişim alanı içinde değerlendirilebilecek araştırmalar olduğu belirlenmiştir. Radyo, Televizyon ve Sinema alanında bahsi geçen konuların dışındaki konularda da tezler bulunmaktadır. 
Alanda araştırma yapacak olan kişilere fikir vermesi bakımından, yayınlanmış tezlerin başlıklarından çıkarılan kategorilerin frekans analizleri aşağıda sunulmuştur.

Tablo 1. Tezlerin Diğer Konu Başlıklarına Göre Dağılımı

\begin{tabular}{|c|c|c|}
\hline Konu Başlıkları: & Siklik (f) & Geçerli Yüzde (\%) \\
\hline Türk Göçmenler & 1 & 0,4 \\
\hline Dijital Etnografi & 1 & 0,4 \\
\hline Dijital Medya & 2 & 0,8 \\
\hline Dijital Oyun & 2 & 0,8 \\
\hline Distopya ve Sinema & 1 & 0,4 \\
\hline Edebiyat Uyarlamaları & 1 & 0,4 \\
\hline Geek Kültürü ve Sosyal Medya & 1 & 0,4 \\
\hline Gerçeküstü Sinema & 1 & 0,4 \\
\hline Görme Biçimleri & 1 & 0,4 \\
\hline Görsel Tarih & 1 & 0,4 \\
\hline Haberde Korku Kültürü & 1 & 0,4 \\
\hline Haberde Yoksul Temsili & 1 & 0,4 \\
\hline Hayvan Belgeselleri ve Ayrımcılık & 1 & 0,4 \\
\hline İnternet Dizileri & 1 & 0,4 \\
\hline İran Sineması & 1 & 0,4 \\
\hline Kamusal Alan & 2 & 0,8 \\
\hline Karşılaştırmalı İletişim Sistemleri & 1 & 0,4 \\
\hline Kitlesel Fonlama & 1 & 0,4 \\
\hline Kültürlerarası İletişim & 1 & 0,4 \\
\hline Küreselleşme ve Medya & 1 & 0,4 \\
\hline Mahremiyet & 1 & 0,4 \\
\hline Medya Çalışanlarının Hakları & 2 & 0,8 \\
\hline Medya Teknolojisi & 1 & 0,4 \\
\hline Medya ve Etik & 1 & 0,4 \\
\hline Mizah ve Erkeklik & 1 & 0,4 \\
\hline Muhalif Sinema & 1 & 0,4 \\
\hline Nostalji ve Mitoloji & 1 & 0,4 \\
\hline Popüler Sinemada Ekoeleştiri & 1 & 0,4 \\
\hline Reality-Showlar & 2 & 0,8 \\
\hline Sanal Diplomasi & 2 & 0,8 \\
\hline Sanal Ortam Uygulamaları & 1 & 0,4 \\
\hline Sinema ve Estetik & 2 & 0,8 \\
\hline Sinema ve Felsefe & 2 & 0,8 \\
\hline Sinema ve Tarih & 1 & 0,4 \\
\hline Sinema ve Gerçekçilik & 1 & 0,4 \\
\hline Sinema ve Korku & 2 & 0,8 \\
\hline Sinemada Oyunculuk & 1 & 0,4 \\
\hline Tartışma Programları & 1 & 0,4 \\
\hline Auter Yönetmenler & 1 & 0,4 \\
\hline Uzaktan Eğitim & 2 & 0,8 \\
\hline Ürün Yerleştirme & 1 & 0,4 \\
\hline
\end{tabular}




\begin{tabular}{lll}
\hline Ütopya, Distopya ve Sinema & 1 & 0,4 \\
\hline Yarı̧ma Programları & 1 & 0,4 \\
\hline Yayın Teknolojileri & 1 & 0,4 \\
\hline Yemek Kültürü & 1 & 0,4 \\
\hline Yeni Medya ve Reklam & 1 & 0,4 \\
\hline Yeni Medya ve Tüketim Kültürü & 1 & 0,4 \\
\hline Yeni Medya ve Yasal Düzenlemeler & 1 & 0,4 \\
\hline Yeni Medyada Ulusçuluk & 1 & 0,4 \\
\hline Yerel Sinema & 1 & 0,4 \\
\hline
\end{tabular}

\section{A.S. Tezlerin Yayınlandıkları Üniversiteler İle Kullanılan Yöntemler Arasında Anlamlı Bir Farklılık Var Mıdır?}

İncelenen üniversitelere göre doktora tezlerinin yöntemi arasında anlamlı bir ilişki olup olmadığına da bakılmıştır. x2 ( $n=260) ; p=0,009<0,05$. Ho hipotezi red, H1 hipotezi kabul edilmiştir. Yani, üniversitelere göre tezlerin dağılımı arasında anlamlı bir farklılık gözlenmiştir. Tezlerde kullanılan yöntemlerin, üniversitelere göre dağılımlarına bakıldığında; incelenen üniversitelerin hepsinde nitel yöntemlerin oranı diğer yöntemlere göre fazla çıkmıştır. Nitel yöntemin en çok kullanıldığ 1 üniversiteler sırasıyla; İstanbul Üniversitesi \%10,7; Ege Üniversitesi \%9,6; Marmara Üniversitesi \%8,8; Ankara Üniversitesi \%2,6; Galatasaray Üniversitesi 2,3; Selçuk Üniversitesi \%1,9; Hacı Bayram Veli (Gazi) Üniversitesi \% 0,7 olarak tespit edilmiştir. Hacı Bayram Veli (Gazi) Üniversitesinde \%0,7 ile nicel yöntemin oranı nitel yöntemle aynı çıkmıştır. Ankara ve Galatasaray Üniversiteleri \%0,4'lük bir oran ile üniversiteler arasında nicel yöntemi en az kullanmışlardır. Bunların dışında; diğer üniversitelere göre daha fazla oranda nicel yöntem çıkmasına rağmen kuruluş tarihi bakımından daha eski oldukları göz önünde tutularak İstanbul \%6,1; Marmara \%3,4 ile nicel yöntemin gözlendiği görülmüştür. Karma yöntemler aç1sından değerlen-dirildiğinde, Hacı Bayram Veli (Gazi) Üniversitesinde hiç karma yönteme rastlanamamışken; karma yöntemin en çok kullanıldığı üniversiteler sırasıyla; \% 3,4 ile İstanbul; \%1,5 ile Marmara; \%1,1 ile Ege, Ankara ve Galatasaray; \%0,4 ile Selçuk Üniversitesi olmuştur. 


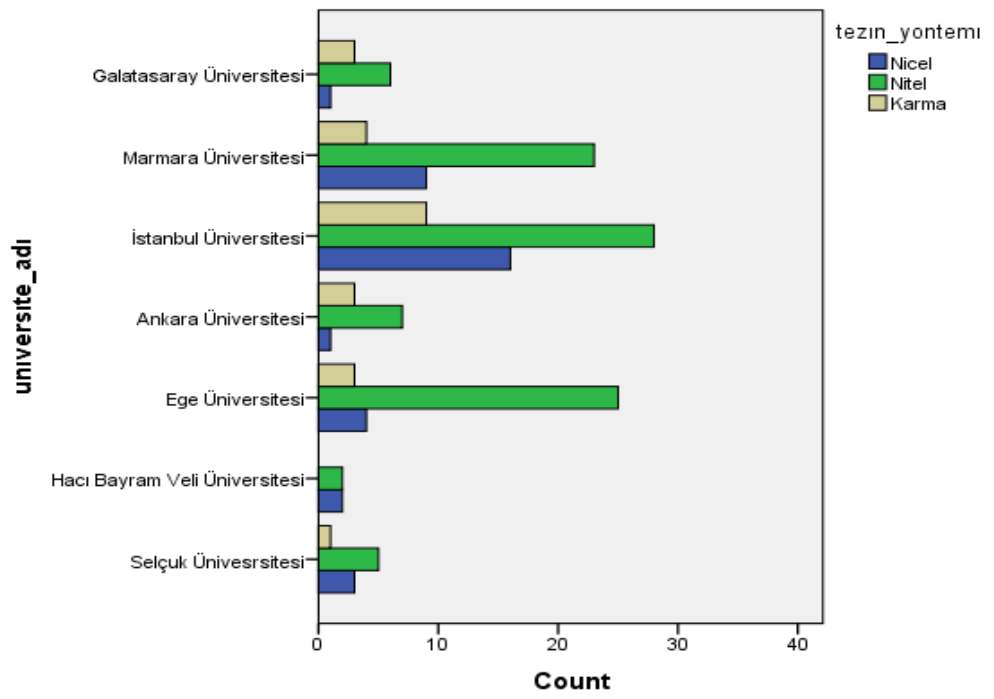

Şekil 2. Tezlerde Kullanılan Yöntemlerin Üniversitelere Göre Dağ̊lımı

Radyo Televizyon ve Sinema Anabilim dalındaki Sinema alanına yönelik tezlerin \%19,2'sinin teorik çalışmalar olduğu, geri kalan \%80,8'inin film incelemelerine dayanan çalışmalar olduğu görülmüştür. Hem film çözümlemelerindeki tez oranının fazla olması hem de doktora tezleri üzerine yapılan kimi araştırmalarda, film incelemelerinden veri analiz teknikleri olarak bahsedilmiş olması nedeniyle, film çözümlemelerine dayalı tezler özelinde de bir inceleme yürütülmüştür. Araştırma bulgularına göre, film çözümlemesi şeklinde geçen tezlerin \%59,3'ünde ( $\mathrm{n}=38)$ herhangi bir yöntem ve teknikten bahsedilmemiş olduğu, \%40,6'sında ise (n=26) kullanılan yöntem ve teknikten bahsedilmiş olduğu görülmüştür. Bununla birlikte, film çözümlemelerine yönelik olarak, yapısalcılık, post-yapısalcılık, eleştirel teori, post-modernleşme, feminist teori gibi kuramlara dayanarak, bu yaklaşımların film incelemesi yaparken veri analiz tekniği şeklinde de sunulmuş olduğu da tespit edilmiştir.

Radyo Televizyon ve Sinema Anabilim dalındaki doktora tezlerin yöntemleri incelendiğinde, çalışmaların en fazla nitel $(\% 36,9)$ en az karma $(\% 8,8)$ araştırma desenine sahip olduğu belirlenmiştir. Doktora tezlerinin \%13,8'inde ise nicel yöntem kullanılmıştır. İletişim alanındaki çalışmalarda yöntemden çok tekniklerin öne çıktığı bilinmektedir. Alandaki çalışmalarda 
veri toplama tekniği olarak anket, son dönem çalışmalarda görüşme ve çeşitleri (odak grup, yarı yapılandırılmış gibi) öne çıkarken; veri analiz tekniklerinden göstergebilim, içerik analizi ve söylem çözümlemeleri sıklıkla kullanılmaktadır. Bu nedenle çalışmada, iletişim alanında en çok tercih edilen bu üç veri analiz tekniğinin kullanımına bakılmıştır.

Tablo 2. Tezlerde Kullanılan Veri Analiz Teknikleri

\begin{tabular}{lll}
\hline Veri Analiz Tekniğinin Adı: & Sıklık (f) & Geçerli Yüzde (\%) \\
\hline Göstergebilim: & 17 & 6,5 \\
\hline İcerik Analizi: & 60 & 23,1 \\
\hline Söylem Çözümlemesi: & 18 & 6,9 \\
\hline Toplam: & 95 & 36,5 \\
\hline
\end{tabular}

İncelenen doktora tezlerinde, yukarıda bahsi geçen veri analiz teknikleri dışında, diğer başlığı altında veri analiz tekniklerine de bakılmıştır. Araştırma sonucuna göre, $\% 4,4$ oranında diğer veri analiz tekniklerinin uygulanmış olduğu tespit edilmiştir. Anlatı çözümlemesi, alımlama analizi, dramaturjik çözümleme, psikanalitik okuma, dramatik çerçeveleme, estetik çözümleme, katmanlar arası teknik ve bağlamsal çözümleme, görüntü çerçeveleme, film adaptasyon tekniği, biçem analizi, ideomitsel analiz teknikleri çalışmada elde edilen diğer veri analiz teknikleridir.

İletişim alanında metin incelemeleri ya da izleyici araştırmalarının dişında, alan araştırmaları, netnografik yöntem, psikobiyografi gibi sosyal bilimlerin farklı metotların da iletişim alanına uyarlandığı görülmüştür. Veri analiz tekniklerinin bazen birlikte bazen de veri toplama teknikleriyle karma yöntemler şeklinde uygulandığı doktora tezleri olduğu da tespit edilmiştir. Doktora tezlerinde uygulanan karma yöntemler incelendiğinde, ya nicel veri toplam tekniği ve nitel veri analiz tekniği birlikte kullanılarak ya da biri nicel biri nitel iki veri analiz tekniğinin birlikte kullanılması yoluyla araştırmanın yapılmış olduğu belirlenmiştir. Örneğin, bazı tezlerde veri toplama tekniği olarak derinlemesine görüşme ve veri analiz tekniği olarak nicel içerik analizinin birlikte uygulandığı, bazı tezlerde ise hem içerik hem söylem analizinin kullanıldığı gözlemlenmiştir. 


\section{A.S. Tezlerin Alanları İle Kullanılan Yöntem Ve Teknikler Arasında Anlamlı Bir Farklılık Var Mıdır?}

Araştırılmak istenilen sorulardan biri de tezin alanı ile tezde kullanılan yöntem arasında anlamlı bir ilişki olup olmamasıydı. Analiz sonucunda, $\chi 2$ ( $\mathrm{n}=260$ ); $\mathrm{p}=0,0001<0,05$. Ho hipotezi red, H1 hipotezi kabul edilmiştir. Yani, tezin alanı ile tezde kullanılan yöntem arasında anlamlı bir ilişki bulunmuştur. Araştırma bulgularına göre, nitel araştırmalara olan eğilim diğer yöntemlere göre $\% 98,4^{\prime} l u ̈ k$ bir oranla daha fazla gözükmektedir. Karma yöntemlerin ise, sinema alanında daha çok (\%17,9'luk bir oranla) kullanıldığı görülmüştür. Radyo Televizyon ve Sinema Anabilim dalını oluşturan üç alana göre tezde kullanılan yöntemlerin sıklıkları sayı ve yüzde olarak Tablo 3.'te gösterilmiştir.

Tablo 3. Tezin Alanına Göre Tezde Kullanılan Yöntemler

\begin{tabular}{lllllll}
\hline & \multicolumn{2}{l}{ Nitel Yöntem } & \multicolumn{2}{l}{ Nicel Yöntem } & \multicolumn{2}{l}{ Karma Yöntem } \\
\hline & Siklı (f) & $\begin{array}{l}\text { Geçerli Yüzde } \\
\mathbf{( \% )}\end{array}$ & Sıklık (f) & $\begin{array}{l}\text { Geçerli } \\
\text { Yüzde (\%) }\end{array}$ & S1klık (f) & $\begin{array}{l}\text { Geçerli } \\
\text { Yüzde (\%) }\end{array}$ \\
\hline Radyo & 1 & 0,1 & 1 & 0,1 & 0 & 0 \\
\hline Televizyon & 30 & 44,7 & 8 & 11,9 & 3 & 4,4 \\
\hline Sinema & 36 & 53,7 & 2 & 2,9 & 12 & 17,9 \\
\hline
\end{tabular}

\section{A.S. Tezlerin Konuları, Kullanılan Yöntem Ve Tekniklere Göre Nasıl Dağılmaktadır?}

Son olarak, Radyo Televizyon ve Sinema Anabilim dalında üretilmiş tezlerin konuları ile en sık tercih edilmeleri bakımından göstergebilim, içerik ve söylem analizlerine göre de nasıl dağıldıkları tespit edilmek istenmiştir. Anlamlı bir veriye ulaşmak için, tezlerdeki her bir konu yerine, sıklıkla geçen konularda kullanılan veri analiz tekniklerine bakılmıştır. Doktora tezlerinin konularının kullanılan veri analiz tekniklerine göre dağılımlarını incelemek için frekans analizi yapılmıştır. 
Tablo 4. Tezin Konularna Göre Tezde Kullanılan Veri Analiz Teknikleri

\begin{tabular}{llllllll}
\hline & \multicolumn{2}{l}{ Göstergebilim } & \multicolumn{2}{l}{ İçerik Analizi } & \multicolumn{2}{l}{ Söylem Analizi } & Toplam: \\
\hline & $\mathbf{( f )}$ & $\mathbf{( \% )}$ & $\mathbf{( f )}$ & $\mathbf{( \% )}$ & $\mathbf{( f )}$ & $\mathbf{( \% )}$ & $\mathbf{( f )}$ \\
\hline Belgesel & 0 & 0 & 2 & 2,9 & 0 & 0 & 2 \\
\hline Yeni Medya & 3 & 4,4 & 8 & 11,7 & 0 & 0 & 11 \\
\hline Radyo Televizyon Yayıncılı̆̆1 & 0 & 0 & 3 & 4,4 & 1 & 1,4 & 4 \\
\hline Türk Sineması & 2 & 2,9 & 2 & 2,9 & 5 & 7,3 & 9 \\
\hline Dünya Sineması & 0 & 0 & 2 & 2,9 & 0 & 0 & 2 \\
\hline Tüketim Kültürü/Popüler Kültü̈r & 1 & 1,4 & 3 & 4,4 & 2 & 2,9 & 6 \\
\hline Ayrımcilı & 0 & 0 & 2 & 2,9 & 2 & 2,9 & 4 \\
\hline Çocuk & 0 & 0 & 4 & 5,8 & 1 & 1,4 & 5 \\
\hline Modernleşme & 3 & 4,4 & 3 & 4,4 & 0 & 0 & 6 \\
\hline Toplumsal Cinsiyet & 1 & 1,4 & 0 & 0 & 1 & 1,4 & 2 \\
\hline Medyanın Ekonomi Politiği & 0 & 0 & 2 & 2,9 & 4 & 5,8 & 6 \\
\hline İzleyici Araştırmaları & 0 & 0 & 2 & 2,9 & 0 & 0 & 2 \\
\hline Siyasal İletişim & 1 & 1,4 & 8 & 11,7 & 0 & 0 & 9 \\
\hline Toplam: & 11 & 15,9 & 41 & 59,8 & 16 & 23,1 & 68 \\
\hline
\end{tabular}

Tezlerin konularına göre veri analiz tekniklerinin kullanım sıklığına bakıldığında, yeni medya konusundaki tezlerde en fazla \%11,7'lik bir oranla içerik analizi; Türk Sineması üzerine olan tezlerde $\% 7,5^{\prime}$ lik bir oranla söylem analizi, radyo televizyon yayıncılığı ile ilgili olan konularda \%4,4 ile içerik analizinin yoğun bir şekilde uygulandığı görülmüştür. Diğer bir dikkat çeken bulgu da modernleşme konusunda olan tezlerin en çok \%4,4 ile göstergebilim analiz veri analiz tekniğinin uygulandığı bulgusudur. Toplumsal cinsiyetle ilgili konular diğer konulara oranla daha sık geçmekle birlikte, veri analiz tekniği açısından değerlendirildiğinde, toplumsal cinsiyetle ilgili tezlerin \% 1,4'lük bir oranla söylem ve göstergebilim analizleri kullanılarak, diğer önemli bir kısmının ise farklı teknikler uygulanarak gerçekleştirilmiş olduğu görülmüştür. Türk Sineması ile ilgili olan tezlerin dışında, söylem analizinin ikinci olarak en çok (\% 5,8 ile) medyanın ekonomi-politiği konusuna ilişkin olduğu tespit edilmiştir. Söylem analizi, metin içinde egemen olan ideolojiyi deşifre etme amacı taşıdığı için medyanın ekonomi-politiğiyle ilgili konularda sıklıkla tercih edildiği düşünülmektedir. Yine, medyada çocuk, ayrımcllık ve tüketim kültürünü konu alan tezlerde ise en çok içerik analizinin tercih edildiği görülmektedir. İdeolojik anlamın ortaya konulması yerine, metnin içeriğine odaklanıldığı için içerik analizinin daha çok tercih edildiği söylenebilmektedir. 


\section{Tartışma ve Sonuç}

Araştırmacıların hazırladıkları doktora tezleri, araştırmacının uzmanlığını ispatladığı, akademik çalışma disiplini kazandığı bir süreç olarak düşünülmektedir. Doktora tezleri bilimsel eserler ortaya koyma iddiasında oldukları için konularının özgünlüğü kadar kullanılan yöntem ve teknikler de önem kazanmaktadır. Diğer yandan, iletişim alanı, tarihsel olarak diğer alanlara göre görece yeni bir alan olması, çok parçalı yapısı, farklı alanlardan gelen akademisyenlerin varlığı, toplumbilimlerin diğer alanlarıyla olan kesişimleri gibi nedenlerle kimi zaman bir alan olarak tartışılmaktadır. Bu durum, İletişim Fakülteleri'nde üretilen tezlerin niteliğini daha da önemli hale getirmektedir. İletişim Fakülteleri'nde üretilen tezlerin niteliğiyle ilgili bilgi sunan ve çoğunlukla nicel yöntem izlenerek yapılan araştırmalarda, anabilim dalının esas alındığı görülmüştür. Benzer şekilde yürütülen araştırmalarda, tezlerin toplam tez sayısı, yayınlandıkları yıl, üniversite isim ve bölümleri, kullanılan yöntem ve teknikler gibi başlıklara göre analizler gerçekleştirilmiştir. Literatür incelendiğinde, Halkla İlişkiler, Gazetecilik ve İletişim Bilimleri Anabilim dallarına yönelik olarak araştırma yürütüldüğü ancak Radyo, Televizyon ve Sinema Anabilim dalına yönelik bir çalışma olmadığ gözlenmiştir. Çalışmanın bu bakımdan en önemli farkı, daha önce bu alana ilişkin lisansüstü tezlerin araştırılmamış olmasıdır.

Diğer araştırmalardan farklı olarak bu çalışmada, tezlerin konularının, alanlara göre nasıl değiştiği de ortaya konulmuştur. Araştırmada tezler konularına ve alanlarına göre bakıldığında, televizyon alanında işlenen konuların televizyon yayıncılığı, haber üretimi noktasında medyanın ekonomi politiği, çocuk ve medya, tüketim kültürü gibi konular üzerinde durduğu tespit edilmiştir. Sinema alanındaki tezlerin ise Türk Sineması, toplumsal cinsiyet, ulusallaşma, Dünya Sineması, modernleşme, bellek gibi konuları ele aldı̆̆ı belirlenmiştir. Diğer çalışma sonuçlarıyla benzer bir biçimde, Türk Sineması üzerine olan doktora tezleri diğer konulara göre fazla çıkmıştır.

Tez konularının birbirini tekrarlaması, bilimsel alandaki çeşitliği düşürerek, aynı şeylerin sürekli bir şekilde üretilmesine, bilimsel çalışmaların kısır bir döngüye girmesine sebep olacağına inanılmaktadır. Bu bakımdan diğer araştırmalardan farklı olarak, Radyo Televizyon ve Sinema Anabilim dalındaki konu başlıkları listelenerek tez başlıklarından kategoriler ve kategorile- 
rin sıklığı da ortaya konulmak istenmiştir. Çalışmada bu başlıklar, alanda çalışma yapmak isteyen araştırmacıları fikir verebilmesi adına listelenerek gösterilmiştir. Araştırmada tespit edilen kategoriler arasında en çok dikkat çekenler, yerel sinema, Geek Kültürü, başkaldırı, sanal diplomasi, yeni medyada yasal düzenlemeler, mizah ve erkeklik, hayvanlara karşı ayrımcılık gibi konular olmuştur. İletişim Bilimleri alanında üretilen doktora tezleri üzerine yapılan araştırmalarda, konuların iletişim sistemleri, yeni medya, medya ve şiddet, küreselleşme, popüler kültür, toplumsal cinsiyet gibi konular olduğu ortaya konulmuştur.

Çalışma sonucunda dikkat çeken bir diğer önemli bulgu da, Radyo Televizyon ve Sinema Anabilim dalında yayınlanmış olan doktora tezlerinin özellikle 2016 yılından sonra arttığının tespit edilmiş olmasıdır. Sosyal medyanın önem kazanmasıyla birlikte görsel kültür öne çıkmış, sinema ve yeni medya çalı̧malarına duyulan ilgi önemli ölçüde arttırmıştır. Diğer bir deyişle, iletişim alanında özellikle "sinema" ve "yeni medya" çalışmak daha da popülerleşmiştir. Radyo Televizyon Sinema Anabilim dalında üretilen tezlerin de, araştırma sonucuna göre, bu gidişattan etkilendiği görülmüştür. Radyo, Televizyon ve Sinema alanında en çok doktora tezinin sinema alanında olduğu, onu yeni medya ve televizyona yönelik çalışmaların izlediği tespit edilmiştir. Radyo alanında ise, önceki araştırmalarla benzer bir şekilde halen çok az sayıda doktora tezinin bulunduğu belirlenmiştir. Artan popüleritesine bağlı olarak, yeni medya konusunda, dijitalleşme, internet teknolojisi ve etkileri, kamusal alan, mahremiyetin dönüşümü gibi konularda daha çok araştırmalar üretilirken, sanıldığının aksine sosyal medya alanındaki tezler üzerine daha az çalışıldığı belirlenmiştir. Yeni medyanın daha çok kullanıc1ların davranışlarını, tutumlarını ölçmeye yönelik çalışmalar ya da siyasal iletişim bağlamında ele alındığı ortaya çıkarılmıştır.

Sinema alanında olan doktora tezlerinde, "modernleşme/post-modernleşme", "uluslaşma/milliyetçilik", "toplumsal cinsiyet", "dijitalleşme", "yeni sinema kültürü ve seyir ilişkisi", "toplumsal bellek" gibi konuların daha sıklıkla ele alındığı gözlemlenmiştir. Toplumsal cinsiyete ilişkin kadın yönetmenler ve filmleri, seçilen filmler üzerinden psikanalitik çözümlemeler, erkeklik çalışmaları gibi konuların işlendiği görülmüştür. Radyo, Televizyon ve Sinema Anabilim dalında yayınlanmış doktora tezlerinde sosyal bilimlerin farklı dallarıyla ve kuramlarıyla ilişki kuran bazı çalışmalarda (teorik ça- 
lışmalar dışında) film incelemelerinin yapıldı̆̆ fakat bazılarında, yöntem k1sımlarının olmadığı tespit edilmiştir. Hatta film inceleyen bazı çalışmalarda, doktora tezinin kuramsal çerçevesini oluşturan ya da yöntemin epistemolojik yaklaşımları olan teorilerden veri analiz tekniği ya da yöntem olarak bahsedildiği görülmüş̧ür.

Üniversitelere göre araştırma sonuçları değerlendirildiğinde, en çok doktora tezi üreten üniversitelerin İstanbul, Marmara, Ege gibi kuruluş tarihi itibariyle daha eski olan üniversiteler olduğu belirlenmiştir. Radyo Televizyon ve Sinema alanında üretilen tezlerde kullanılan yöntem ve teknikler incelendiğinde, iletişim alanındaki yakın dönemdeki çalışmalarla benzer bir biçimde en çok kullanılan yöntemin nitel yöntem olduğu sonucuna ulaşılmıştır. Alanda üretilen doktora tezlerinde nicel ve karma yöntemlerin de uygulandığı tespit edilmiştir.

Yayınlanan doktora tezlerinin üniversitelere göre yönteminin değişip değişmediğine de bakılmıştır. Araştırma sonucunda, incelenen üniversiteler arasında her üç yöntemi de İstanbul Üniversitesi'nin diğerlerine göre daha fazla kullandığı görülmüştür. İstanbul Üniversitesi'nde gerek tez gerekse yöntemlerin oranının diğerlerine göre fazla çıkmasının nedeni daha eski ve köklü üniversite olması şeklinde yorumlanmıştır. İstanbul Üniversitesi d1şında, diğer üniversiteler değerlendirildiğinde; nitel yöntemi en çok uygulayan üniversitenin Marmara Üniversitesi, karma yöntemi ise Marmara ile birlikte Ege ve Galatasaray Üniversitesi'nin uyguladığı görülmüştür.

Özellikle son zamanlarda, hem Türkiye'de hem de dünyada sosyal bilimler alanında karma yöntemlerin birbirini tamamladığı için daha çok tercih edildiği gözlenmektedir. Bu bakımdan, Radyo Televizyon ve Sinema Anabilim dalındaki doktora tezleri içinde karma yöntemlerin kullanılması, çalışmada önemli bir sonuç olarak değerlendirilmiştir. Yine, sinema alanıla benzer bir biçimde televizyon alanında üretilen tezlerde kullanılan iletişim aracının kendisinden çok "ayrımcllk", "modernleşme", "çocuk", "popüler kültür", "medyanın ekonomi politiği", "felsefe" gibi konular üzerinden çalışıldığ 1 tespit edilmiştir.

İncelenen doktora tezlerinde, iletişim alanında metin incelemeleri ya da izleyici araştırmalarının dışında, alan araştırmaları, netnografik yöntem, psikobiyografi gibi sosyal bilimlerin farklı metotların da Radyo Televizyon ve Sinema alanındaki doktora tezlerine uyarlandığı görülmüsştür. Ancak, bilimsel bir çalışmanın önemli kısımlarından biri olan yöntem kısımlarının bazı 
tezlerde hiç bulunmaması, iletişimin sosyoloji, psikoloji gibi disiplinlerle kurulan ilişkisinde, diğer disiplinlerden gelebilecek olan "iletişim alanın bir disiplin olamadığı" yönündeki iddialara da açık kapı bırakacağı düşünülmektedir. Diğer yandan, yöntem ve tekniğin belirtilmemiş olması, alandaki durumun tespiti için, tezler üzerine çalışmak isteyen araştırmacıların bu bilgilere ulaşamamasına da neden olacaktır. 


\section{EXTENDED ABSTRACT}

\section{A Content Analysis on Phd Theses in the Depart-ment of Radio, Television and Cinema \\ Çilem Tuğba Koç \\ Erciyes University}

Under the circumstances such as the increase in the number of newly established communication faculties; new media departments such as cinema and photography are emerged as a separate departments; cinema education is also provided from the faculties of fine arts etc., the quality of the education have become more crucial mostly argued among the media scholars. In the literature, it is seen that there were researches on the quality of postgraduate studies produced in the field of communication, but the studies on doctoral theses were not found in the department of Radio, Television and Cinema, in particular. With this necessity, 260 doctoral dissertations have been analyzed using content analysis method. In order to provide an outline of the last ten years, the theses produced between the years of 2010 and 2020, have been collected from YOK's National Thesis Searching Page and evaluated according to the publishing year, name of the university; subject, field, methods and techniques were used.

In terms of the methods applied in these theses, the studies have been carried out mostly by using qualitative method (36.9\%), by quantitative method(13.8\%) and mixed method (8.8\%). Examining the three fields separately, it is found that quantitative and qualitative methods were used with a rate of $0.2 \%$ in radio studies; qualitative methods with $44.6 \%$, quantitative with $11.9 \%$ and mixed methods with $4.4 \%$ were applied in the field of television; $53.7 \%$ qualitative, $2.9 \%$ quantitative and $17.9 \%$ mixed methods were used in cinema. In terms of data analysis techniques, it has been observed that $23.1 \%$ of studies designed by content analysis, $6.9 \%$ of them by discourse analysis and $6.5 \%$ of them by semiotics data analysis techniques. Apart from the mentioned techniques, we run across the other other data analysis techniques with a rate of $44 \%$. Narrative analysis, interpretation analysis, dramaturgical analysis, psychoanalytic reading, dramatic framing, aesthetic analy- 
sis, interlayer technical and contextual analysis, image framing, film adaptation technique, style analysis, ideomitic analysis techniques were defined as other data analysis techniques applied in the examined theses.

Another striking determination of the study is regarding to the publishing year. It is obtained that after the year 2016, doctoral theses have been started to produce and the theses were mostly published from the universities such as Istanbul, Marmara and Aegean which are considered as the oldest according to their establishment date. With the ever increasing importance of social media, visual culture has come to the fore and the interest in cinema and new media studies has increased significantly. In other words, in particular "cinema" and "new media" have become more popular in the department of Radio Television and Cinema. Regarding the number of the theses, cinema field came first among the other fields in the department of Radio Television and Cinema. Similar to the previous researches, it has been determined that there are still very few doctoral dissertations in the field of radio.

According to the topics of the theses; $5.3 \%$ of the studies are related to radio and television broadcasting. In the field of television, $2.3 \%$ of the studies are based on the political economy of the media; $1.5 \%$ of them on children; $1.5 \%$ of them are related to modernization, $1.4 \%$ to consumption culture, and $1.1 \%$ to news. The high number of theses in the field of cinema caused the ratio of thesis topics to be higher than the other three fields. The most prominent subjects in the field of cinema are; $14.6 \%$ is Turkish Cinema, $4.3 \%$ is gender; $3.4 \%$ is digitalization; $3.07 \%$ of the World Cinema; $3.8 \%$ of nationalization and modernization; $1.9 \%$ is documentary. It has been clarified that $1.5 \%$ of these studies focus on social memory issues. Along with these, subjects such as children, discrimination, consumer culture, news, animation, Islamophobia, identity and representation, film aesthetics, cinema audience, film aesthetics have also been encountered. Among the new media studies, new communication technologies have gained weight with a rate of $6.5 \%$. In this context, it has been brought out that studies dealing with the concept of "network society" and studies examining the effects of internet technology on television broadcasting and digitalization have gained importance in the field of new media. Political communication such as the effect of social media on social movements and its power to create public opinion were also defined as other topics in the field of new media. In the study, categories and the frequency of categories among doctoral dissertation titles have also been revealed. The 
subjects were identified as local cinema, Geek Culture, rebellion, virtual diplomacy, legal regulations in new media, humor and masculinity, discrimination against animals.

\section{Kaynakça / References}

Akgül, M. ve Akdağ, M. (2018). İletişim eğitimi ve disiplinlerarasıllk: İletişim fakültelerindeki akademisyen profili üzerine bir değerlendirme. Türkiye İletişim Araş̧trmalan Dergisi, 31, 1-20.

Avc1, N. (1998). Iletişim düşüncesinin gelişimi: Eğitim-öğretim boyutlarula bir model denemesi. Eskişehir: Anadolu Üniversitesi Yayınları.

Aziz, A. (2006). Dünyada ve Türkiye' de iletişim araştırmaları. Kültür Illetişim Dergisi, 9(1), 9-31.

Davulcu, E., ve Tanyeri Mazıı, E. (2018). İletişim araştırmalarında 2006-2016 yılları arasinda yapılan doktora tezlerine ilişkin bir durum değerlendirmesi. Karadeniz Üniversitesi İletişim Fakültesi Dergisi, 10, 55-73.

Değirmenci, K. (2011). Sosyal bilimlerde disiplinlerarasıllğı ve disipliner ayrımları yeniden düşünmek. Akdeniz Üniversitesi İletişim Fakültesi Dergisi, İletişim Eğitimi Özel Sayısı, 15, 72-80.

İnceoğlu, Ç. (2014). Türkiye'de sinemayı konu alan doktora tezleri üzerine bibliyometrik bir çözümleme. Galatasaray Üniversitesi IIleti-ş-im Dergisi, 21, 32-47.

Pooley, J. ve Park, D. W. (2012). Communication research. P. Simonson, J. Peck, R. T. Craig, J. P. Jackson, Jr (Der.), The Handbook of History Communication içinde (s.76-90). London: Routledge.

Riffe, D., Lacy, S., ve Fico, G. F. (2014). Analyzing media messages. New York: Routledge.

Rogers, E. W. (2004). Theoretical diversity in political communication. L. L. Kaid (Ed.), Handbook of Political Communication Research içinde (s.3-16). NJ: Lawrence Erlbaum Associates Publishers.

Tokgöz, O. (2006). Türkiye'de iletişim fakültelerinde eğitim kadrosunun durumu. Kültür ve İletişim, 9(1), 33-69.

Tufan, F. (2019). Türkiye'de radyo alanında içerik analizi yöntemiyle yüksek lisans ve doktora tezleri üzerine bir inceleme. Gümüşhane Üniversitesi IIletişim Fakültesi Dergisi, 7(1), 110-130.

Uzun, R. (2006). İstihdam sorunu bağlamında Türkiye'de iletişim eğitimi ve öğrenci yerleştirme. İetişim ve Kuram Araştırma Dergisi, 25, 117-134.

Ünlü, S., N, A., ve D, T. (1999). Anadolu Üniversitesi Illetişim Bilimleri Fakültesi Mezunlarının fakültesindeki eğitim hakkındaki görüşleri üzerine bir araştırma. İletişim, 4, 91-109. 
Kaynakça Bilgisi / Citation Information

Koç, Ç. T. (2021). Radyo, televizyon ve sinema anabilim dalındaki doktora tezleri üzerine bir içerik analizi. OPUS-Uluslararası Toplum Araştırmalar Dergisi, 17(33), 674-700. DOI: 10.26466/opus.832924 